\title{
Analysis of Sharia Commercial Banking Capital
}

\author{
Soeharjoto \\ \{ryoto16@yahoo.com\}
}

Fakultas Ekonomi dan Bisnis Universitas Trisakti, Jakarta Barat, Indonesia

\begin{abstract}
Purpose of this study is to determinate non performance financing (NPF) effect and return on asset in the previous period $(\operatorname{ROA}(-1))$ against capital of sharia banks (CAR). Using regression method with monthly time series data from 2014-2018, which comes from Financial Services Authority (OJK). Result shown that NPF have negative effect and significant to CAR and ROA(-1) have a positive and significant effect towards CAR.
\end{abstract}

Keywords: CAR, NPF, ROA(-1)

\section{Pendahuluan}

Perekonomian dunia pada era milenial semakin sensitif dalam menghadapi perubahan global. Indonesia juga mengalami gejolak ekonomi, yang merupakan dampak dari krisis global. Untuk mengantisipasikan agar tidak terjadinya krisis yang berkelanjutan, diperlukan strategi dengan kebijakan untuk mengamankan sektor perbankan, karena memiliki sifat yang dapat berdampak pada sistematic risk. Kondisi ini, sudah disadari pihak perbankan dari berbagai belahan dunia, yang akhirnya membuat kesepakatan dengan dibuatkannya kebijakan global regulatory framework for more resilient banks and banking system pada Basel III (1). Adapun kesepakatan penting yang dibuat, berupa perlu dilakukannya tindakan untuk meningkatkan kualitas dan level permodalan yang lebih tinggi, dengan agenda utama pada common equity dan perlunya ketersediaan cadangan modal, dengan cara dibentuknya conservation buffer dan countercyclical buffer. Regulasi ini dibuat untuk mengamankan perbankan agar tidak rentan terutama dalam menghadapi krisis global.

Indonesia sebagai negara G20, turut serta dalam menjalankan regulasi Basel III. Adapun kebijakan yang diambil pemerintah dengan cara memberlakukannya terhadap perbankan nasional, tetapi secara bertahap, karena bagi perbankan dirasakan berat, namun wajib dijalankan, agar perbankan nasional tidak mengalami kesulitan likuiditas, yang akan berakibat kepercayaan masyarakat akan hilang dan industri perbankannya mengalami kebangkrutan, yang memberikan dampak systemic risk pada perekonomian nasional (Soeharjoto, 2018) (2). Untuk mengantisipasi kondisi tersebut, Bank Indonesia pada 2014 membuat program Arsitektur Perbankan Indonesia (API), dengan tujuan memperkuat permodalan bank, guna meningkatkan kemampuan bank dalam mengelola usaha maupun risiko.

Perbankan Indonesia yang menggunakan dual system, yakni perbankan konvensional dan syariah. Perbankan konvensional sudah banyak yang mapan karena keberadaannya yang terlebih dahulu dibandingkan perbankan syariah. Begitu pula halnya yang terjadi pada saat perbankan nasional dalam menghadapi Basel III. Hal ini, dapat tercermin dari kondisi capital 
adequacy ratio (CAR) perbankan nasional lebih tinggi dari pada perbankan syariah (Gambar $1)$.

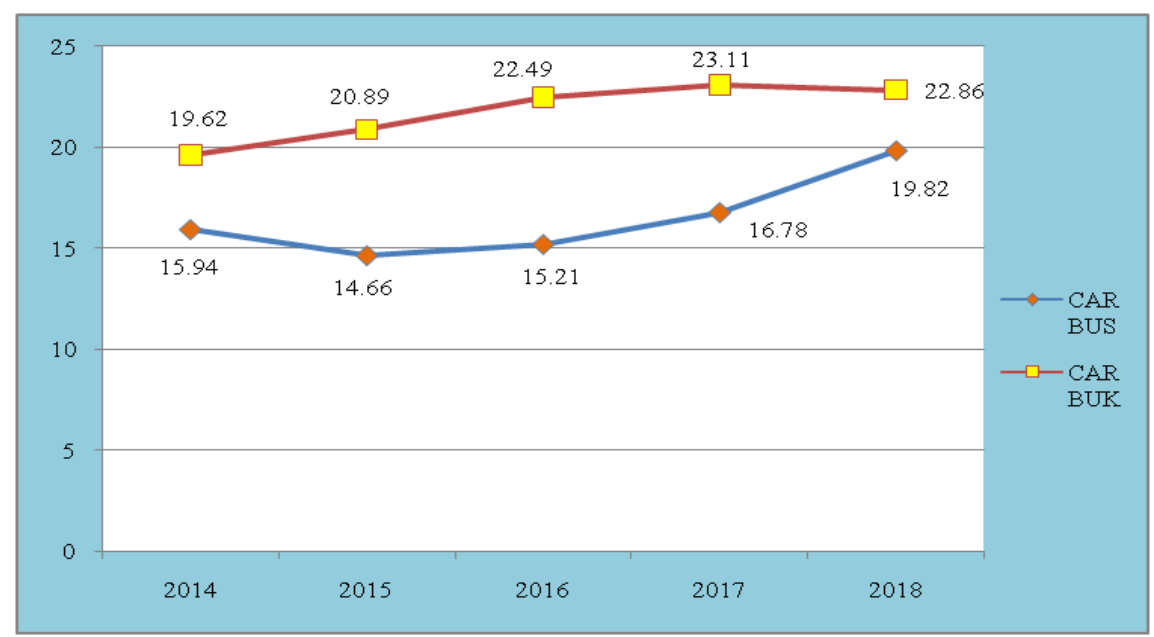

Gambar 1. Capital Adequacy Ratio (CAR) Bank Umum Syariah dan Bank Umum Konvensional di Indonesia, Pada 2014-2018 (Persen) Sumber: OJK (3)

Penduduk Indonesia yang mayoritas beragam Islam, dalam menjalankan aktivitasnya di bidang ekonomi, banyak yang mnginginkan untuk melakukannya sesuai dengan syariatnya. Bank umum syariah merupakan fasilitas yang dimiliki dan dapat digunakan umat sebagai solusinya. Namun, perkembangan dari perbankan syariah tidak sepesat perbankan konvensional, terutama terkait dengan permodalan. Apalagi pada era financial technology (fintech), bertambah lagi saingannya, terutama dari perusahaan yang berasal dari luar negeri, yang memiliki modal besar (Tribudhi dan Soeharjoto, 2019 ; triyuwono (2006) (4),(5). Padahal, perbankan syariah juga dapat mempergunakan fasilitas fintech guna menunjang kinerjanya.

Kinerja CAR bank dapat dipengaruhi nilai return on asset (ROA) dan Non Performing Financing (NPF). Indikator performance sebuah bank menggunakan profitabilitas (ROA). Dengan demikian, apabila ROA semakin besar, akan menyebabkan laba meningkat, sehingga alokasi dana yang digunakan untuk modal (CAR) juga akan bertambah. Kualitas aktiva yang baik tergantung dari tingkat kolektibilitasnya, sehingga bank yang memiliki kolektibilitas tinggi dengan earning asset yang cukup, maka kebutuhan modalnya dapat dibiayai dari keuntungan yang diperoleh. Dengan demikian, bila terjadi pembiayaan bermasalah (NPF), akan menurunkan jumlah pendapatan yang akan diterima bank, sehingga bank akan menggunakan modal yang ada untuk membiayai kegiatan operasionalnya, yang mengakibatkan modal bank akan terkikis, sehingga berdampak pada penurunkan jumlah CAR. Untuk itu, perlu dilakukan penelitian yang terkait dengan faktor-faktor yang mempengaruhi capital adequacy ratio (CAR), terutama non performance financing (NPF) dan return on asset (ROA) pada periode sebelumnya (ROA(-1)). NPF memiliki peran yang penting terkait dengan risiko yang dihadapi perbankan dan $\mathrm{ROA}(-1)$ terkait dengan keuntungan yang dapat diperoleh perbankan pada periode sebelumnya. 


\section{Landasan Teori}

Semua pihak yang terlibat baik secara langsung dan tidak langsung dalam melakukan pengelolaan perusahaan selama ini, terus mengalami perbaikan menuju pada adanya kerjasama semua pihak (partnership) secara fair untuk kesejahteraan bersama. Hal ini, terbukti dengan berkembangnya teori yang menuju pada kesadaran bahwa perlu adanya keadilan dengan cara perusahaan dapat dijadikan nara sumber untuk penghidupan yang lebih layak bagi semua manusia yang ada di bumi ini dengan menjaga lingkungannya. Teori keagenan menurut Jensen dan Meckling (1976), mengungkapkan adanya hubungan kerja antara pemilik perusahaan (principal) dan manajemen (agent), namun prinsipal tidak boleh mencampuri urusan teknis (6) dalam operasi perusahaan, walaupun pihak prinsipal yang memberikan wewenang kepada agen (7). Menurut Dowling dan Pfeffer (1975), legitimasi merupakan hal yang penting bagi organisasi, karena organisasi merupakan bagian dari masyarakat, sehingga perlu memperhatikan norma sosial masyarakat, agar perusahaan memperoleh legitimate (8). Teori Stakeholder menurut Friedman (1962) menganggap perusahaan bukanlah entitas yang hanya beroperasi untuk kepentingan sendiri, namun harus memberikan manfaat kepada seluruh stakeholder-nya (9). Teori enterprise menurut Adolf (1947), bahwa perusahaan dalam menjalamkan bisnisnya, jangan hanya mementingkan pemilik perusahaan saja, namun juga pihak lain yang memberikan kontribusi baik secara langsung dan tidak langsung kepada perusahaan. Teori enterprise merupakan cikal bakal dari perkembangan shariah enterprise teori, yang mengungkapkan bahwa Allah sebagai pencipta dan pemilik tunggal dari seluruh sumber daya yang ada di dunia ini, dengan demikian bagi stakeholders memperoleh amanah dari Allah SWT, untuk memanfaatkan sumber daya yang ada dengan cara dan tujuan yang ditetapkan oleh Allah SWT, yakni untuk kesejahteraan bersama tanpa merusak alam (10).

Kesehatan bank menjadi penting karena adanya keterkaitan kepentingan dari semua pihak yang terlibat, yakni pemilik, manajemen, dan masyarakat. Adapun alat ukur yang digunakan adalah rasio keuangan dari Van Horne dan Wachowicz. (2008) (11). Untuk itu, Bank sentral mengeluarkan penilaian tingkat kesehatan bank dengan mengeluarkan Peraturan Bank Indonesia Nomor 13/1/PBI/2011 tentang Penilaian Tingkat Kesehatan Bank Umum, yang diukur dari CAMELS, yang meliputi aspek permodalan (capital), kualitas asset (asset quality), manajemen (management), rentabilitas (earnings), likuiditas (liquidity), dan sensitivitas terhadap risiko pasar (sensitivity to risk market). Penelitian ini, menggunakan beberapa rasio keuangan yang dapat mewakili tingkat kesehatan bank, yakni permodalan atau Solvabilitas yang merupakan kemampuan perusahaan untuk memenuhi kewajiban baik jangka pendek maupun jangka panjang dengan pendekatan capital adequacy ratio (CAR), kualitas aktiva produktif yang merupakan tolok ukur untuk menilai tingkat kemungkinan diterimanya kembali dana yang ditanamkan dalam aktiva produktif berdasarkan kriteria tertentu dengan pendekatannon performing financing (NPF), Rentabilitas atau profitabilitas digunakan untuk mengukur tingkat efisiensi usaha dan profitabilitas yang dicapai dengan menggunakan return on asset (ROA).

Hubungan NPF terhadap CAR

NPF merupakan pinjaman yang mengalami kesulitan pelunasan akibat adanya unsur kesengajaan atau pun akibat unsur eksternal diluar kendalinya debitur. Peningkatan NPF mengindikasikan terdapatnya peningkatan kredit bermasalah terhadap total kredit yang dimiliki bank, yang akan mengakibatkan pendapatan yang seharusnya diterima dari bagi hasil pinjamannya akan mengalami penurunan, sehingga akan menurunkan laba bank, yang berdampak pada penurunan CAR. Kondisi tersebut sesuai dengan penelitian Andhika, dkk (2017), Raharjo, dkk (2014), Abusharba, dkk (2013) yang mengungkapkan bahwa terdapat 
pengaruh yang negatif dan signifikan antara NPF dan CAR.Adapun hipotesisnya adalah NPF berpengaruh negatif terhadap CAR (1),(12),(13).

Hubungan ROA(-1) terhadap CAR

ROA merupakan kemampuan manajemen bank dalam memperoleh laba secara keseluruhan. Peningkatan ROA akan meningkatkan keuntungan bank, sehingga dari segi penggunaan asetnya bank semakin baik, yang akhirnya berdampak pada peningkatan CAR. Hal ini sesuai dengan penelitian Wilara dan Basuki (2016), Kurniawan, dkk (2014), Buyuksalvarcy dan Abdioglu (2011) yang mengungkapkan bahwa ROA berpengaruh positif terhadap CAR. Adapun hipotesisnya adalah ROA(-1) berpengaruh positif terhadap CAR (14),(15),(16).

\section{Metode Penelitian}

Penelitian ini bertujuan untuk mengetahui pengaruh NPF dan ROA(-1) terhadap CAR, dengan metode regresi, yang menggunakan data runtun waktu berupa bulanan, pada 2-142018, yang berasal dari OJK. Variabel bebasnya NPF dan ROA(-1) dengan variabel terikatnya CAR. Adapun persamaannya:

CAR

$$
\mathrm{CAR}=\beta_{0}+\beta_{1} \mathrm{NPF}+\beta_{2} \mathrm{ROA}(-1)+\varepsilon_{0}
$$

NPF $\quad=$ Non Performing Financing (Persen).

ROA $(-1) \quad=$ Return on Asset peride sebelumnya (Persen).

\section{Hasil dan Pembahasan}

Bank umum Syariah di Indonesia dengan indikator ketetapan Peraturan Bank Indonesia No. 13/1/PBI/2011 pasal 2, tentang penilaian tingkat kesehatan bank dengan menggunakan pendekatan risiko baik sercara individu ataupun konsolidasi, pada 2014.1-2018.12, memiliki CAR dalam kategori sangat sehat karena memiliki nilai rata-rata 16,48 persen, yang berada di atas 12 persen, dengan nilai antara 14,09 persen hingga 21.39 persen. NPF masuk dalam kategori sehat karena nilai rata-ratanya sebesar 4,74 persen, yang berada pada antara 2 persen5 persen, yakni antara 3,22 persen hingga 6,17 persen. $\mathrm{ROA}(-1)$ dalam kategori cukup seha memiliki nilai rata-rata sebesar 0,85 persen, yang berada antara 0,5 persen hingga 1,25 persen, dengan nilai anatara 0,08 persen hingga 1,41 persen.

Tabel 1. Deskripsi Variabel Penelitian

\begin{tabular}{l|r|r}
\hline Variabel & \multicolumn{1}{|c|}{ Mean } & \multicolumn{1}{c}{ Std. Deviation } \\
\hline CAR & 16.4756 & 1.98874 \\
\hline NPF & 4.7453 & .65857 \\
\hline ROA(-1) & 0,8520 & 0,32783 \\
\hline \multicolumn{2}{l|}{ Sumber; Data Hasil Olahan } \\
\hline
\end{tabular}


Hasil perhitungannya diperoleh nilai $\mathrm{F}$ sebesar 23,974 dengan sig. 0,000, karena nilai sig. lebih kecil dari 0,05, bermakna bahwa secara simultan variabel NPF dan ROA $(-1)$ berpengaruh terhadap variabel CAR. Adapun nilai koefisien determinasinyanya $\left(\mathrm{R}^{2}\right)$ sebesar 0,461 yang memiliki arti bahwa variabel NPF dan ROA(-1) dapat menjelaskan terhadap variabel CAR sebesar 46,1 persen, sedangkan siasanya yang 53,9 persen dijelaskan oleh variabel lain yang tidak dimasukkan ke dalam model.

Tabel 2. Data Hasil Diolah

\begin{tabular}{|c|c|c|c|c|c|c|}
\hline \multirow{2}{*}{\multicolumn{2}{|c|}{ Model }} & \multicolumn{2}{|c|}{$\begin{array}{c}\text { Unstandardized } \\
\text { Coefficients }\end{array}$} & \multirow{2}{*}{$\begin{array}{c}\text { Standardized } \\
\text { Coefficients } \\
\text { Beta } \\
\end{array}$} & \multirow[b]{2}{*}{$\mathrm{t}$} & \multirow[b]{2}{*}{ Sig. } \\
\hline & & $\mathrm{B}$ & $\begin{array}{l}\text { Std. } \\
\text { Error }\end{array}$ & & & \\
\hline \multirow[t]{3}{*}{1} & (Constant) & 23.646 & 1.578 & & 14.986 & .000 \\
\hline & NPF & -1.796 & .299 & -.595 & -6.014 & .000 \\
\hline & $\operatorname{ROA}(-1)$ & 1,796 & .600 & .261 & 2.643 & .011 \\
\hline
\end{tabular}

Sumber: Data Hasi Olahan

Hasil pengujian individu (uji t) untuk masing-masing variabel independen diperoleh hasil untuk pengujian pengaruh dari NPF terhadap CAR ditunjukkan dengan nilai koefisien sebesar -1,796 dengan sig. 0,000 yang berada dibawah 0,05 memiliki arti bahwa dengan meningkatnya NPF akan menurunkan CAR dan sebaliknya, menurunnya NPF akan menaikkan CAR. Hasil temuan ini menunjukkan hipotesis teori yang menyatakan NPF berpengaruh negatif terhadap CAR terbukti. Hasil pengujian pengaruh dari ROA(-1) terhadap CAR ditunjukkan dengan nilai koefisien estimasi 1,796 dengan sig. 0,011 yang berada dibawah 0,05, memiliki arti bahwa dengan meningktnya $\operatorname{ROA}(-1)$ akan meningkatkan CAR dan sebaliknya menurunnya ROA(-1) akan menurunkan CAR. Hasil temuan ini menunjukkan bahwa hipotesis teori yang menyatakan $\operatorname{ROA}(-1)$ berpengaruh positif terhadap CAR terbukti.

\section{Simpulan dan Saran}

NPF dan ROA(-1) terhadap CAR mempunyai nilai koefisien determinasinyanya $\left(\mathrm{R}^{2}\right)$ sebesar 0,461. NPF mempunyai pengaruh yang negatif dan signifikan terhadap CAR. ROA(1) mempunyai pengaruh yang positif dan signifikan terhadap CAR. Untuk meningkatkan CAR bank umum syariah perlu meningkatkan tambahan modal dengan mengajak investor baik dari pemerintah, masyarakat dan luar negeri. Namun, dalam menyalurkan pinjaman pihak bank umum syariah perlu mengutamakan prinsip kehati-hatian walaupun kondisi perekonomian sedang tumbuh dan pinjaman yang diberikan sebaiknya diperuntukkan bagi pengembangan sektor riil. 


\section{References}

1. Andhika YD, Suprayogi N. Faktor-faktor yang mempengaruhi Capital Adequacy Ratio (CAR) bank umum Syariah di Indonesia. J Ekon Syariah Teor Dan Terap. 2017;4 (4):132.

2. Soekapdjo S, Nugroho L, Badawi A, Utami W. Bad Debt Issues in Islamic Bank: Macro and Micro Influencing (Indonesia Cases). Int J Commer Financ. 2018;4(1):10 26.

3. www.ojk.co.id.

4. Tribudhi, Aryani D, Soekapdjo S. Determinasi transaksi dengan menggunakan uang elektronik di Indonesia. KINERJA. 2019;16(1):78-84.

5. Triyuwono I. Perspektif, Metodologi, dan Teori Akuntansi Syariah. 2006.

6. Jensen M, Meckling W. Theory of the firm: Managerial behaviour, agency costs and ownership. Strateg Manag J [Internet]. 1976;21(4):1215-24. Available from: http://search.ebscohost.com/login.aspx?direct=true \&db=buh\&AN=12243301\&site=eh ost-live

7. Jensen MC, Meckling WH. Theory of The Firm: Managerial Behavior, Agency Costs and Ownership Structure. J financ econ [Internet]. 1976 [cited 2019 Jun 26];3:305-60. Available from: http://117.211.153.211:8001/jspui/bitstream/123456789/335/1/1-s2.00304405X7690026X-main.pdf

8. Dowling J, Pfeffer J. Organizational legitimacy: Social values and organizational behavior. Pac Sociol Rev. 1975;18(1):122-36.

9. Friedman M. Capitalism and Freedom University of Chicago Press. Chicago (Capitalisme Lib Paris, Robert Laffont). 1962;

10. Berle AA. The theory of enterprise entity. Columbia Law Rev. 1947;47.3:343-58.

11. Van Horne JC, M J. Wachowicz Jr. "Fundamentals of." Financial Management. 2005.

12. Abusharba MT. Determinants of capital adequacy ratio (CAR) in Indonesian Islamic commercial banks. Glob Rev Account Financ. 2013;4.1:159-70.

13. Raharjo PG. Determinant of capital ratio: A panel data analysis on state-owned banks in Indonesia. Bul Ekon Monet Jan Perbank. 2014;16(4):395-414.

14. Buuml A, Abdioğlu H. Determinants of capital adequacy ratio in Turkish Banks: A panel data analysis. African J Bus Manag. 2011;5.27:11199-209.

15. Kurniawan AT, Lestari S. ANALISIS FAKTOR-FAKTOR YANG 
MEMPENGARUHI CAPITAL ADEQUACY RATIO (CAR). Sustain Compet Advant. 2014;4(1).

16. Wilara GR, Basuki AT. Determinan Ketahanan Modal Bank Syariah di Indonesia: Pendekatan ECM. J Ekon Stud Pembang. 2016;17(2):157-67. 